\title{
Using purposeful inbreeding to reduce outbreeding depression caused by escaped farmed Atlantic cod
}

\author{
Olivia A. Puckrin ${ }^{1, *}$, Craig F. Purchase ${ }^{1}$, Edward A. Trippel ${ }^{2}$ \\ ${ }^{1}$ Fish Evolutionary Ecology Research Group, Memorial University of Newfoundland, St. John's, \\ Newfoundland A1B 3X9, Canada \\ ${ }^{2}$ Fisheries and Oceans Canada, St. Andrews Biological Station, St. Andrews, New Brunswick E5B 2L9, Canada
}

\begin{abstract}
Fish often escape from aquaculture operations, raising concerns of interactions with wild individuals. Farmed fish from genetically diverse populations grown outside their native range create the threat of outbreeding depression if they escape and interbreed with wild fish. Atlantic cod Gadus morhua spawn within cages, releasing millions of embryos into the environment, some of which may live to reproduce. Due to selective breeding, fewer breeding individuals are used in culture relative to wild populations, potentially leading to inbreeding within single cages. If inbreeding reduces survival, this could reduce the likelihood of outbreeding depression if maturing escaped cod mate with wild cod. Forced inbreeding could be used to mitigate some effects of aquaculture on the environment. We aimed to determine if cod inbreed and, if so, what short-term effects inbreeding has on offspring. Spawned embryos from tanks of sister-brotherunrelated male trios underwent microsatellite analysis to determine parentage. Inbreeding occurred, and females did not prefer one type of male over the other. Percent hatch, deformities, larval size, and mortality were monitored in artificially fertilized inbred and unrelated crosses. Percent hatch was higher in non-inbred offspring, but inbreeding had no significant effect on the other factors.
\end{abstract}

KEY WORDS: Gadus morhua - Local adaptation - Inbreeding - Escape through spawning · Embryo deformities $\cdot$ Larval survival $\cdot$ Microsatellite DNA

\section{INTRODUCTION}

The aquaculture industry is growing as the global production and demand for fish continues to increase (Naylor et al. 2000, Brander 2007). As with any industry, there are environmental concerns, including disease transmission (Heggberget et al. 1993), pollution from animal waste and excess feed (Ackefors \& Enell 1994, Kelly et al. 1996), and the use of large quantities of wild fish as feed (Naylor et al. 2000). Another concern is the escape of farmed fish and their possible negative interactions with wild fish (Thorstad et al. 2008). In the case of Atlantic salmon Salmo salar, occurrences of escapes have been reported in a number of countries, in small or very large numbers (Naylor et

*Email: opuckrin@gmail.com al. 2005). Farmed Atlantic salmon currently outnumber wild salmon, and escapees represent up to $50 \%$ of fish in spawning populations in Norwegian rivers (Skaala et al. 2006). Outbreeding depression (see below in this subsection) has been reported as a result of spawning between escaped and wild salmon (McGinnity et al. 2003), and the progeny of farmed-wild salmon offspring have been shown to be less fit than their non-hybrid wild counterparts (McGinnity et al. 2003). Much less is known for similar issues with other cultured species, including Atlantic cod Gadus morhua. Cod also happen to have a much higher rate of escape than salmon, because, among other things, they actively bite at the cage netting (Moe et al. 2009, Zimmermann et al. 2012). For example, from 2001 to

(C) Puckrin, Purchase, and Fisheries and Oceans, Canada 2013. Open Access under Creative Commons by Attribution Licence. Use, distribution and reproduction are unrestricted. Authors and original publication must be credited.

Publisher: Inter-Research · www.int-res.com 
2009 Norwegian Atlantic salmon escaped at a rate of $0.19 \%$, while cod escaped at a rate of at $1.02 \%$ (Jensen et al. 2010). However, cod pose an additional problem. Unlike farmed salmon, which will not spawn in sea cages, Atlantic cod do (Bekkevold et al. 2002, Jørstad et al. 2008). In the wild, cod form spawning aggregates for a period of roughly 2 mo in the winter. They are broadcast spawners, and provide no parental care for their offspring (Hutchings et al. 1999). The females are repeat spawners, and produce an average of 8 batches over the course of the spawning season, releasing millions of eggs over a few months (Bekkevold et al. 2002). The chosen male ventrally mounts the female, matching her speed, and grasping her with his pelvic fins; they align genital pores and release their gametes (Brawn 1961a). Other males may eject sperm near the mating couple in an attempt to fertilize some eggs-these males are referred to as satellite or 'sneaker' males (Nordeide \& Folstad 2000, Rudolfsen et al. 2005). In the wild, while a female may spawn millions of eggs in a single spawning season, only a few will ever reach maturity (Svåsand et al. 2000). Given that farmed cod spawn in the cages, embryos with cultivated cod genes drift out of sea cages into the environment, escaping through spawning (Jørstad et al. 2008, Jensen et al. 2010). If they survive, they may interact with wild cod with possible negative implications, including competition for food and other resources, mating competition, and outbreeding depression (Hansen et al. 2008). If the fish have been intensely selected for domestication, they can introduce domestic adaptations that disrupt local adaptations of wild cod (Hindar et al. 1991).

Outbreeding depression occurs when genetic differences of interbreeding populations produce offspring with reduced fitness as a result of incompatible genes, often in the form of lost local adaptation (Dobzhansky 1950, Edmands 1999). For example, they may be more vulnerable to changes in the environment (e.g. changes in water temperature, predation, disease, food availability) (Fleming et al. 2000, McGinnity et al. 2003, Weir et al. 2005, Hutchings \& Fraser 2008, Jensen et al. 2010). Outbreeding depression can happen when non-native farmed fish escape from sea cages and spawn with a local wild population (Hutchings \& Fraser 2008). In the case of Atlantic cod, this includes escaped embryos that survive and mature. Cultivated species may be grown outside of their natural range (e.g. Atlantic salmon in Chile) or within their range (e.g. Atlantic salmon in Norway) (Bekkevold et al. 2006). At a finer scale, farmed individuals may be raised within the natural species range, but the specific population under culture may not be from the local area. Thus, the captive fish may be genetically adapted to a set of unique environmental conditions different from those of the cage site (Read \& Fernandes 2003), where they are fed, medicated for diseases, and protected from predators (Read \& Fernandes 2003, Bekkevold et al. 2006, Hutchings \& Fraser 2008). If escaped fish interbreed with wild ones, local adaptations of the wild fish may be disrupted through introgression in the hybrid offspring, reducing their fitness (Read \& Fernandes 2003, Bekkevold et al. 2006). This has been seen in populations of Northwest Atlantic salmon, where the farmed broodstock originated mainly from wild salmon in non-acidified rivers. However, the rivers that many escaped salmon have inhabited over time are acidified and contain locally adapted wild salmon (Fraser et al. 2008). When the escaped farmed salmon spawn in the wild, the hybrid offspring have been found to be maladapted and to suffer decreased survival rates (Fraser et al. 2008). Interbreeding between non-local cultivated and wild Atlantic cod could have similar results. Due to past fishing efforts, many wild cod populations are already struggling (Hutchings 1991, COSEWIC 2010), and interbreeding with escaped farmed cod, whether inbred or not, could be detrimental to their overall survival. Aquaculture could be responsible for 2 means of genetic pollution through introgression: the introduction of both farmselected, and also potentially non-native genes into wild populations (McGinnity et al. 1997, Edmands 1999, Fraser et al. 2008). It is therefore important to minimize interactions between farmed and wild cod.

Several strategies for reducing the reproductive abilities of farmed cod have been explored. Photoperiod manipulation, which hinders farmed Atlantic salmon from maturing, has been attempted with Atlantic cod without success (Trippel et al. 2011a). Triploidy can be used to create females that do not mature, but is not effective for males, which would be capable of spawning with wild cod if they escaped (Feindel et al. 2011). In this study we explored forced within-cage single generation inbreeding as another possible tool to mitigate the long-term effects of escaping embryos on wild cod populations, should inbred offspring face significantly reduced fitness and survival. Although there is currently no commercial cod farming in Canada, besides those dedicated to selective breeding (Trippel et al. 2011b), stocking of juveniles in sea cages in New Brunswick used to be performed in such a way that $95 \%$ of the cod were likely to have been produced by 2 females and the remaining $5 \%$ from opportunistic spawners; the potential for inbreeding was high (G. Nardi, Great- 
Bay Aquaculture, pers. comm. 2011). The same scenario would likely exist again if production of fish for market recommences. There are possibly 1000s of related cod within a sea cage, which already creates a large potential for inbreeding, but also enables stocking strategies to be arranged such that any embryo production from cages would have to come from full sibling matings.

Typically inbreeding, the mating of closely related individuals, results in inbreeding depression, a reduction of offspring fitness for any number of given traits (Kincaid 1983). Studies have shown that inbreeding in fish, even at the half-sibling level, can result in reduced egg fertilization, decreased survival of larvae, and smaller sized offspring (Mrakovčič \& Haley 1979, Auld \& Relyea 2010), as well as an increase in the occurrence of deformities in rainbow trout (Aulstad \& Kittelsen 1971, Aulstad et al. 1972, Mrakovčič \& Haley 1979). Growth rate, body weight, and food conversion efficiency at different stages of development have also been affected by inbreeding depression (Kincaid 1976a,b, Gjerde et al. 1983). Inbreeding is particularly common in aquaculture, where the desired selection of specific traits may narrow the number of viable candidates for broodstock development. Eknath \& Doyle (1990) found that using fewer breeders in a broodstock can result in reduced genetic variation as a result of inbreeding. Inbreeding depression has been seen in captive rainbow trout (Su et al. 1996), and the potential exists for inbreeding depression among haddock as well, if no wild broodstock are used to enhance genetic variation periodically (Trippel et al. 2009). If the effects of inbreeding in cultivated Atlantic cod are severe enough, inbreeding could potentially be used as a tool to mitigate the effects of escaping cod embryos from sea cages. By only stocking grow out cages with related fish, the resultant first generation of inbred embryos that drift out after spawning may face decreased hatch success, higher incidence of potentially lethal deformities, and less likelihood of reaching maturity, all of which could reduce the risk of farmed offspring interacting with wild cod (Kincaid 1983). However, the implications of even a few inbred offspring surviving and interbreeding with wild cod must be seriously considered. Farmed fish already pose a threat to hybrid offspring survival (McGinnity et al. 2003). Factors that could play an important role in cod reproduction are the ability of cod to recognize related individuals, and the mechanisms behind mate selection. Kin recognition and mate choice may be of particular importance when it comes to the potential for inbreeding among spawn- ing cod in cages. While some species of fish, juvenile salmonids and threespine stickleback Gasterosteus aculeatus for example, are thought to be able to recognize related individuals (Fitzgerald \& Morrissette 1992, Ward \& Hart 2003), other species, such as haddock Melanogrammus aeglefinus and guppies Poecilia reticulate, do not appear to share this ability (Viken et al. 2006, Trippel et al. 2009). It is not yet known whether cod can recognize related individuals, or if this would affect their mate choice.

Previous research has been undertaken on inbreeding in various marine species, and on deformities in cod and other fish, but this is the first study to our knowledge to examine the occurrence of inbreeding among cultivated Atlantic cod and the direct effects on first generation offspring. The objectives of this study were to investigate the feasibility of inbreeding as a tool to reduce the genetic impacts of escapes through spawning on wild cod populations, particularly outbreeding depression. To do this we needed to determine whether or not Atlantic cod inbreed in captivity and to examine the effects of inbreeding on offspring characteristics. Given that we do not know whether or not Atlantic cod are capable of kin recognition, we hypothesized that female cod do not differentiate between potential mates based on relatedness, and predicted no bias toward unrelated males over related males. We also hypothesized that inbreeding results in reduced offspring survival and poor offspring quality (i.e. higher mortality, reduced size, and higher incidence of deformities) compared to non-inbred offspring. If inbreeding occurs and significantly reduces the likelihood of offspring fitness, we propose that further research could be done to determine whether or not this reduction in farmed offspring survival could reduce the overall occurrence of outbreeding depression that can result from farmed-wild cod hybridization.

\section{MATERIALS AND METHODS}

\section{In vivo spawning experiment - Will cod inbreed?}

The study specimens of Gadus morhua were fish from the Atlantic Cod Genomics and Broodstock Development Project (Cod Genome Project, http:// codgene.ca; Trippel et al. 2011b), created in 2005; they were reared in captivity and held at the St. Andrews Biological Station (Fisheries and Oceans Canada, St. Andrews, New Brunswick, Canada). Fish used were from F1 generation families created 
from the original wild broodstock, captured in the Bay of Fundy (Northwest Atlantic Fisheries Organization, Division 4X). The study specimens were fed a mix of herring Clupea harengus, northern shortfin squid Illex illecebrosus and Aesop shrimp Pandalus montagui for $1 \mathrm{yr}$ prior to the start of the experiment and a marine grower diet prior to that; they were not fed for the duration of the spawning season (Fordham \& Trippel 1999). Fish were 4 yr old, with known family backgrounds, and had had successful spawnings in previous years. All individuals were weighed and measured in mid-January 2010, and Fulton's condition factor, which is important in cod mating, was calculated for each fish $\left(K=W L^{-3} \times 100 ; \pm 0.1\right)$ (Kjesbu et al. 1996, Trippel \& Neil 2004). Trios consisted of a mature female, a full-sibling brother, and an unrelated male. The trios were chosen by family background, and the males were matched by weight, length, and condition factor to reduce morphological features that may influence female mate choice or male dominance (Table 1). On 3 February 2010, 30 cod were transferred from a holding tank and placed in their pre-assigned trios in ten $3000 \mathrm{l}$ circular tanks $\left(3 \mathrm{~m}^{3}, 1.83 \mathrm{~m}\right.$ diameter, and $1.17 \mathrm{~m}$ deep $)$.

Seven fish died during the experiment. Of the 4 tanks that had mortalities, egg batches were only collected from 1 of them (Trio 1 produced 1 batch before the female died). The 3 females that died were 'egg bound' (female fails to release eggs but continues to ovulate; Árnason \& Björnsson 2012). Some of the dead fish were replaced as there were suitable fish still in the holding tank. Replacements had to fit the family requirements (related or unrelated as needed), and had to closely match the other fish in the trio in length, weight, and condition factor (Rakitin et al. 2001).

Each tank was equipped with a surface egg-collector that was checked daily for fertilized eggs, as well as a collector over the outflow pipe for dead eggs (Thorsen et al. 2003). Eggs from the surface egg-collector were examined under a dissecting scope for fertilization; 20 embryos (minimum) from each batch were removed and preserved in $95 \%$ ethanol for genetic analyses. Additional embryos were preserved whenever quantities allowed. The embryos were almost all collected within $24 \mathrm{~h}$ of spawning. However, a few of the batches of embryos were only a few hours old at the time of collection. These embryos were incubated for no longer than $2 \mathrm{~d}$ to minimize differential losses due to different sires that could skew the parentage analysis (Saillant et al. 2001, Trippel et al. 2005). Average daily water temperatures during the experiment ranged from 5.7 to $6.3^{\circ} \mathrm{C}$.
Table 1. Gadus morhua. Length $(\mathrm{cm})$, weight $(\mathrm{kg})$, and Fulton's condition factor $(K)$ of each Atlantic cod used in the in vivo competitive spawning experiment, as well as replacement fish used due to death of an originally assigned cod (Rep: replacement; F: female; B: brother; NB: non-brother). Family designations illustrate the relatedness of each fish, where the same family number indicates fish that are full siblings. The females in trios 6 to 10 did not spawn (egg bound or died and either had no suitable replacement or the replacement female was also egg bound or died)

\begin{tabular}{|c|c|c|c|c|c|}
\hline Trio & Fish & Family & Length $(\mathrm{cm})$ & Weight (kg) & $K$ \\
\hline \multirow[t]{3}{*}{1} & $\mathrm{~F}$ & 1 & 64.1 & 4.31 & 1.64 \\
\hline & $\mathrm{B}$ & 1 & 64.0 & 3.54 & 1.35 \\
\hline & NB & 4 & 65.0 & 3.84 & 1.40 \\
\hline \multirow[t]{3}{*}{2} & $\mathrm{~F}$ & 2 & 61.5 & 4.30 & 1.85 \\
\hline & $\mathrm{B}$ & 2 & 53.0 & 3.50 & 2.35 \\
\hline & NB & 8 & 53.6 & 3.42 & 2.22 \\
\hline \multirow[t]{3}{*}{3} & $\mathrm{~F}$ & 3 & 63.7 & 4.71 & 1.82 \\
\hline & B & 3 & 61.1 & 4.22 & 1.85 \\
\hline & NB & 9 & 59.3 & 4.38 & 2.10 \\
\hline \multirow[t]{3}{*}{4} & $\mathrm{~F}$ & 4 & 67.9 & 5.33 & 1.70 \\
\hline & B & 4 & 67.5 & 5.08 & 1.65 \\
\hline & NB & 8 & 65.1 & 4.26 & 1.54 \\
\hline \multirow[t]{3}{*}{5} & $\mathrm{~F}$ & 5 & 62.2 & 4.23 & 1.76 \\
\hline & $\mathrm{B}$ & 5 & 60.5 & 3.76 & 1.70 \\
\hline & NB & 9 & 59.9 & 3.16 & 1.47 \\
\hline \multirow[t]{4}{*}{6} & $\mathrm{~F}$ & 6 & 57.9 & 3.02 & 1.55 \\
\hline & $\mathrm{B}$ & 6 & 56.7 & 2.21 & 1.21 \\
\hline & NB & 5 & 54.7 & 2.23 & 1.36 \\
\hline & Rep NB & 4 & 62.6 & 3.21 & 1.31 \\
\hline \multirow[t]{3}{*}{7} & F & 7 & 70.9 & 5.15 & 1.44 \\
\hline & $\mathrm{B}$ & 7 & 69.7 & 4.79 & 1.41 \\
\hline & NB & 6 & 68.8 & 4.23 & 1.30 \\
\hline \multirow[t]{6}{*}{8} & $\mathrm{~F}$ & 8 & 64.3 & 3.51 & 1.32 \\
\hline & $\mathrm{B}$ & 8 & 62.5 & 3.59 & 1.47 \\
\hline & NB & 9 & 62.5 & 4.46 & 1.83 \\
\hline & Rep F & 4 & 73.2 & 5.24 & 1.34 \\
\hline & Rep B & 4 & 62.6 & 3.21 & 1.31 \\
\hline & Rep NB & 8 & 61.3 & 2.89 & 1.26 \\
\hline \multirow[t]{3}{*}{9} & F & 4 & 65.0 & 4.90 & 1.78 \\
\hline & $\mathrm{B}$ & 4 & 64.0 & 3.93 & 1.50 \\
\hline & NB & 1 & 59.9 & 3.29 & 1.53 \\
\hline \multirow[t]{3}{*}{10} & $\mathrm{~F}$ & 5 & 61.2 & 3.90 & 1.70 \\
\hline & B & 5 & 60.0 & 3.36 & 1.56 \\
\hline & NB & 9 & 60.6 & 3.38 & 1.52 \\
\hline
\end{tabular}

On 29 March 2010 the experiment was terminated and the fish were euthanized. The barbel was removed from each adult cod and preserved in $95 \%$ ethanol for genetic analyses.

\section{DNA extraction}

Tissue from the preserved barbels was used to genotype the adults, and embryos were used whole 
and intact. Adult tissue and embryo DNA extractions were performed following the Wizard SV 96 Genomic DNA Purification System protocol for animal tissues (Promega A2370), with a slight alteration. Instead of adding $250 \mu \mathrm{l}$ of nuclease-free water to each well of the binding plate and incubating for $2 \mathrm{~min}$, repeating for a total of $500 \mu \mathrm{l}$, we added $75 \mu \mathrm{l}$ of nuclease-free water and incubated for 10 to $15 \mathrm{~min}$, repeating for a total of $150 \mu \mathrm{l}$. DNA from the adult tissue was diluted to $25 \mathrm{ng} \mathrm{ll}^{-1}$ based on Nanodrop readings (Nanodrop ND-1000 Spectrophotometer, Thermo Scientific). Nanodrop readings for the embryos reported values that exceeded the margin of error for the reader.

Multiplex design and DNA amplification

A pre-existing protocol (Wesmajervi et al. 2006) was used as a guide, with slight alterations. Four microsatellites were used (Gmo8, Gmo19, Gmo35, and Gmo37) instead of the 5 in Wesmajervi et al. (2006) (Tch11 did not work in any of our attempts, and so was removed from the multiplex). Given that each embryo from any tank could only have 1 female and 1 of 2 possible fathers, the microsatellites used provided a power of exclusion of $100 \%$ in a population of 2 males. To increase the number of successfully genotyped embryos, we used Q PCR Master Mix (5 $\mu \mathrm{l}$ ) (Quiagen), Q Solution (1 $\mu \mathrm{l}$ ) (Quiagen), $3.6 \mu \mathrm{l}$ of DNA template, and $0.4 \mu \mathrm{l}$ of the primer Master Mix (concentration of each primer in mix: $0.6 \mu \mathrm{M}$ Gmo8 forward and reverse, $0.5 \mu \mathrm{M}$ Gmo19 forward and reverse, $0.5 \mu \mathrm{M}$ Gmo35 forward and reverse, and $0.4 \mu \mathrm{M}$ Gmo37 forward and reverse) for an amplification reaction volume of $10 \mu \mathrm{l}$. The polymerase chain reaction (PCR) was carried out in a BioRad C1000 thermo cycler, and the thermal cycling parameters were as follows: denaturation at $95^{\circ} \mathrm{C}$ for $15 \mathrm{~min}, 35$ amplification cycles at $94^{\circ} \mathrm{C}$ for $30 \mathrm{~s}, 57^{\circ} \mathrm{C}$ for $90 \mathrm{~s}$, and $72^{\circ} \mathrm{C}$ for $90 \mathrm{~s}$, then after the 35 cycles, $72^{\circ} \mathrm{C}$ for $10 \mathrm{~min}$, and down to $10^{\circ} \mathrm{C}$ to finish.

\section{DNA analysis}

Adult tissue PCR products were diluted 1:20 in nuclease-free water. Due to the low yields from DNA extractions of the small number of cells found in 1 to 3 d embryos, embryonic PCR products were analyzed without dilution. For a $10 \mu \mathrm{l}$ reaction mix, we added $4 \mu \mathrm{l}$ of the PCR product, $0.2 \mu \mathrm{l}$ of GeneScan500-LIZ size standard (Invitrogen), and $5.8 \mu \mathrm{l}$ of HiDi
Formamide (Invitrogen). The samples were heated for $3 \mathrm{~min}$ at $95^{\circ} \mathrm{C}$ and immediately placed on ice to cool before being placed in either a 3130 or 3730 Genetic Analyzer (ABI 3130 and 3730 DNA Analyzer, Applied Biosystems). Data from both the 3130 and the 3730 analyzers were compared to ensure that results did not differ between machines. Peak Scanner Software (Version 1.0, Applied Biosystems, 2006) was used to read the allele sizes, and parentage was assigned by matching allele sizes between adults and embryos within a trio.

\section{Statistical analysis}

A log-likelihood goodness of fit G-test was performed to determine if there was a significant difference in the proportion of eggs sired by each male within a batch for each trio (all tests had 1 degree of freedom) (McDonald 2009). Statistical analyses were executed in Excel (McDonald 2009).

\section{In vitro artificial fertilization - Do inbred cod have depressed fitness?}

Gametes were stripped from 5 yr old captive Atlantic cod from the Atlantic Cod Genomics and Broodstock Development Project, provided by the Huntsman Marine Science Centre (St. Andrews, New Brunswick, Canada). Complete family history was known for these fish. Aquacalm $\left(0.2 \mathrm{~g} \mathrm{l}^{-1}\right.$; Syndel International, Vancouver, BC, Canada) was used to sedate fish before they were anaesthetized with MS222 (76 mg l-1, Aqualife TMS, Syndel Laboratories) (Butts et al. 2009). Once anaesthetized, the area surrounding the genital pore was wiped dry and pressure was applied to the abdomen to expel the eggs into a dry 11 plastic beaker. Semen was collected from the males in a similar manner, using a dry $40 \mathrm{ml}$ glass beaker, and making sure that no blood or urine entered the sample. Gametes were stored for no longer than $1 \mathrm{~h}$ before use, and were kept at $6^{\circ} \mathrm{C}$ immediately after collection.

Artificial fertilization was carried out in a refrigerated room at $6^{\circ} \mathrm{C}$. All equipment was rinsed with UVsterilized salt water, and then dried and chilled. Egg batches from each of 14 females were divided in half, one-half fertilized with the semen of a full-sibling brother, and the other half with the semen of an unrelated male (Fig. 1). Eggs were placed in a large glass beaker (size of beaker was at least double the volume of eggs), and approximately $10 \mathrm{ml}$ seawater was 
added. Semen was then pipetted directly onto the eggs at a ratio of $1 \mathrm{ml}$ of semen for every $100 \mathrm{ml}$ of eggs, stirred with a glass rod, and left for $3 \mathrm{~min}$, after which the water level in the beaker was brought up to double the volume of eggs. After $10 \mathrm{~min}$, excess sperm was removed from the embryos by rinsing them through a fine mesh net with $1 \mathrm{l}$ of seawater. The embryos were then placed in a 1.51 'stock' beaker topped up with seawater. The embryos were left in the stock beaker to incubate overnight. Embryos from 14 females were artificially fertilized between 23 February and 31 March 2010. Among the 14 females, 10 families were represented (some females were sisters). Each family was considered a replicate.

\section{Embryo deformities}

For 7 of the females we were able to photograph their fertilized embryos at the 2- to 4 -cell stages after overnight incubation and examined them for visual malformations in early cell cleavage patterns. In the remaining 7 crosses the embryos had already progressed past the 4-cell stage before they could be photographed. A small random sample of embryos

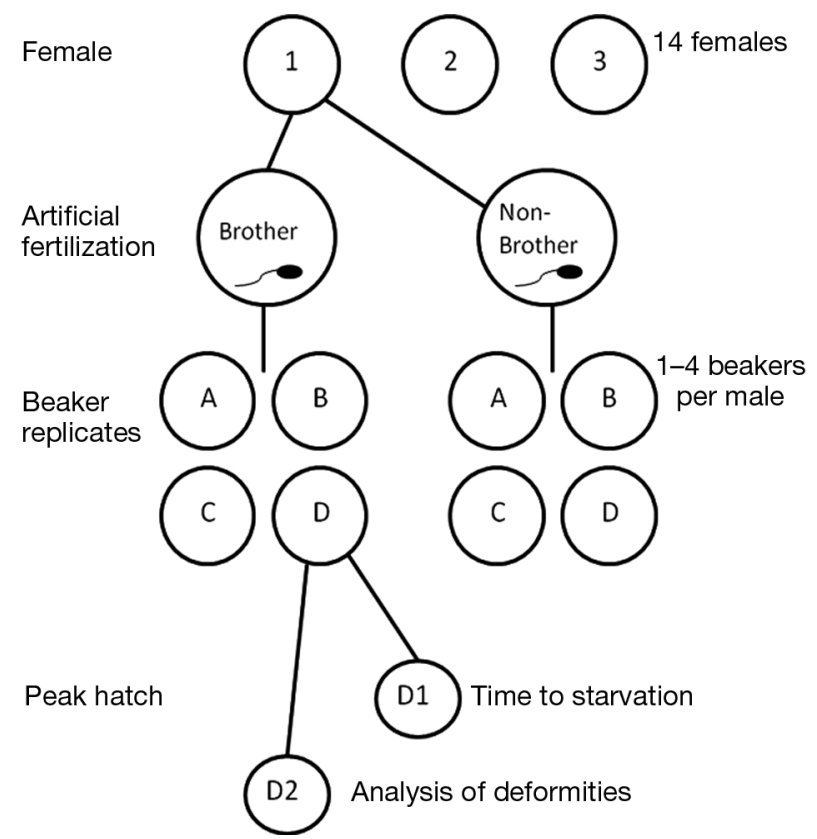

Fig. 1. Gadus morhua. Illustration of artificial fertilization process. Eggs from each female Atlantic cod were equally divided by volume and crossed with sperm from a full-sibling brother or an unrelated male and incubated overnight. Embryos from each cross were divided equally into $250 \mathrm{ml}$ beakers until hatch. At peak hatch the larvae from each beaker replicate were removed and subdivided into $50 \mathrm{ml}$ beakers for measurement of deformities and time to starvation was removed from the stock beaker. Samples consisted of approximately 20 embryos from each cross, and these embryos were photographed for visual analyses of asymmetrical development. Photographs of the inbred and unrelated embryos were analyzed for the presence of malformations in random order to reduce potential bias, and the average number of deformities per embryo was determined, based on pre-existing criteria (Shields et al. 1997, Avery et al. 2009). A blastodisc was considered normal if it had 4 distinct, symmetrical cells of equal size. The following embryo deformities were identified based on illustrations and images by Avery et al. (2009) and Shields et al. (1997): asymmetrical cells, uneven number of cells, unequal cell size, incomplete intercell adhesion, poorly defined cell margins, vacuolar inclusions between cells, overlapping cells, extra cell bodies, triple (only 3 cells, 1 larger, 2 smaller), jumbled cells (cells of varying size and position), offset/intermediate (the 4 cells do not all meet at 1 central point), pie (the 4 cells resemble a pie in shape), and marginal (cells equal in size, but with 3 cells forming a rough circle and the fourth on the outside of the circle).

\section{Embryo rearing and percent hatch}

After overnight incubation, fertilized embryos, which float at the surface of the beaker, were divided into a maximum of four $250 \mathrm{ml}$ beakers of seawater with 250 to 300 embryos in each (the exact number of embryos in each beaker was counted; some had fewer embryos due to lower fertilization success) (Fig. 1). Where fertilization success was low, the embryos were divided into fewer than 4 beakers, but these beakers had an embryo density similar to that of crosses with higher fertilization success. The temperature was maintained at $6^{\circ} \mathrm{C}$, and a $50 \%$ water change was performed daily for each beaker to maintain water quality. Any dead embryos (opaque and negatively buoyant) and hatched larvae were enumerated and removed daily enabling estimation of percent hatch.

\section{Larval survival and quality}

On the day of peak hatch (the largest single-day hatching event for each beaker), the larvae were randomly divided in half and placed into two $50 \mathrm{ml}$ beakers of seawater. One of these beakers was used to monitor the time to starvation. Daily dead were 
recorded and removed until all larvae had died. Fifty percent water changes were carried out every other day. Data from individual beakers were pooled for each male in every cross from peak hatch until $100 \%$ mortality was reached. The mean percent daily survival was calculated from the average of all inbred and unrelated crosses.

The other group was used to determine larval quality. On the day of peak hatch, 5 larvae were randomly selected from this group and photographed along the lateral view while under a dissecting scope so that they could be measured and examined for deformities. Larval measurements were taken at hatch and at $5 \mathrm{~d}$ post hatch (dph) using Image-Pro Plus (Version 5.1.0.20, Media Cybernetics) and included total body length, myotome height, eye diameter, yolk area (not including yolk sac), and jaw length at Day 5 only, once fully developed (Rideout et al. 2004).

\section{Larval deformities}

From the larval photographs taken at hatch, the presence and type of 4 possible deformities were recorded for each larva. Previous work on larval deformities mainly examined spinal deformities in larvae past the yolk sac stage (Aulstad \& Kittelsen 1971, Gjerde et al. 1983), although a few studies identified various other deformities as well (e.g. jaw, finfolds, and yolk sac) (Hart \& Purser 1995, Kennedy et al. 2000). Any characteristic that deviated from 'normal' (straight body, full yolk sac at hatch) was considered a deformity and included: bent tail end, bend in midsection, curved body, and malformed yolk sac, where the yolk appeared shrivelled or misshaped at hatch. The number of deformed larvae, the average number of deformities per deformed larva, and the occurrence of each type of deformity was recorded for each cross. Larvae were discarded after photographing. Where only 1 embryo hatched in a beaker, that larva was used to estimate time to starvation; no photographs were taken as handling may have affected survival. That cross was eliminated from all of the larval size measurement and deformities analysis.

\section{Statistical analysis}

Data for females that were in the same family were averaged for statistical analyses, as were data from the beakers for each male in a cross. Sample sizes were as follows: $\mathrm{N}=10$ independent comparison groups (20 half-sibling families) for embryo deformi- ties and hatch data, and $\mathrm{N}=9$ for larval deformities, time to starvation, and size measurements. A paired $t$-test was used to compare differences between inbred and non-inbred offspring hatch data, and the occurrence of embryo deformities (arcsine-transformed proportions; Sokal \& Rohlf 1995). The same test was used on untransformed means to determine if there was a difference in the mean number of deformities per deformed embryo. A general linear model (GLM) was used to compare the prevalence of deformities among larvae using arcsine-transformed proportions (GLM: Deformities $=\beta_{\text {Cross }} \times$ Cross + $\beta_{\text {Relatedness }} \times$ Relatedness $+\varepsilon$ ), and untransformed means were used with the same GLM to determine if there was a difference in the mean number of deformities per deformed larva. The following GLM was used to analyze time to starvation between inbred and non-inbred crosses: Larval survival $=\beta_{\text {Cross }} \times$ Cross $+\beta_{\text {Relatedness }} \times$ Relatedness $+\beta_{\text {Day }} \times$ Day $+\varepsilon$. Body length, myotome height, eye diameter, and yolk area were analyzed with the GLM: Measurement variable $=\beta_{\text {Cross }} \times$ Cross $+\beta_{\text {Relatedness }} \times$ Relatedness $+\beta_{\text {Day }} \times$ Day $+\varepsilon$, to account for measurements taken at hatch and at $5 \mathrm{dph}$. An interaction term (Relatedness $\times$ Day) was included initially, but found not to be significant and, therefore, so was removed from the model. Jaw length, measured only at $5 \mathrm{dph}$, was analyzed using a paired $t$-test. A Bonferroni correction was applied to the size measurement data to account for multiple tests of size, with the resulting $\alpha$ $=0.01$. Statistical analyses were performed using Minitab (Version 15.1.1.0).

\section{RESULTS}

\section{In vivo competitive spawning experiment}

Only 5 of the 10 trios of cod spawned. These trios produced 1 to 10 batches, with an average of 3.8 batches (Table 2). Of the 19 batches from all spawning trios, single paternity was observed in 5 batches, all of which were fertilized by the unrelated male in each trio. Multiple paternity occurred in the rest of the batches $(n=14)$, some of which were dominated by the brother. The brother did not have sole paternity of any batches. There was a significant difference in the number of eggs fertilized by each male within a batch for all trios, with the exception of 2 batches in Trio 2, where each male fertilized approximately half the batch. For the majority of the batches, 1 male dominated spawning (Table 2). Of the 5 trios that spawned, the unrelated male had the greatest 
Table 2. Gadus morhua. Number of batches produced by each trio of Atlantic cod that spawned and the number of genotyped embryos sired by each male per batch, and pooled for the trio (percent of total eggs for batch/trio shown in parentheses). A total of 19 batches were produced. The log-likelihood goodness-of-fit $G$-test was used to determine whether there was a significant difference in the proportion of embryos sired by each male within a batch $(\alpha=0.05, \mathrm{df}=$ 1 for all batches)

\begin{tabular}{|c|c|c|c|c|c|}
\hline Trio & Batch & Brother & Unrelated & $G$-value & $\mathrm{p}$ \\
\hline 1 & 27 Feb & $2(4.3)$ & 44 (95.7) & 47.32 & $<0.001$ \\
\hline \multirow[t]{11}{*}{2} & Pooled & $66(17.6)$ & $310(82.4)$ & 171.91 & $<0.001$ \\
\hline & $15 \mathrm{Feb}$ & $1(5.9)$ & $16(94.1)$ & 15.96 & $<0.001$ \\
\hline & 16 Feb & 0 & 36 (100) & 49.91 & $<0.001$ \\
\hline & 17 Feb & $1(7.1)$ & 13 (92.9) & 12.2 & $<0.001$ \\
\hline & 19 Feb & 0 & $24(100)$ & 33.27 & $<0.001$ \\
\hline & 23 Feb & $3(7.3)$ & 38 (92.7) & 35.37 & $<0.001$ \\
\hline & 25 Feb & $1(3.1)$ & 28 (96.6) & 31.50 & $<0.001$ \\
\hline & 2 Mar & $2(4.2)$ & 46 (95.8) & 49.91 & $<0.001$ \\
\hline & 9 Mar & $12(18.5)$ & 53 (81.5) & 27.97 & $<0.001$ \\
\hline & 11 Mar & $25(52.1)$ & $23(47.9)$ & 0.08 & 0.773 \\
\hline & 15 Mar & 21 (38.9) & 33 (61.1) & 2.69 & 0.101 \\
\hline \multirow[t]{4}{*}{3} & Pooled & $1(0.98)$ & $101(99.02)$ & 130.16 & $<0.001$ \\
\hline & $11 \mathrm{Feb}$ & 0 & $21(100 \%)$ & 29.11 & $<0.001$ \\
\hline & $12 \mathrm{Feb}$ & 0 & $39(100 \%)$ & 54.07 & $<0.001$ \\
\hline & 20 Feb & $1(2.4)$ & $41(97.6)$ & 48.77 & $<0.001$ \\
\hline \multirow[t]{3}{*}{4} & Pooled & $27(87.1)$ & 4 (12.9) & 19.13 & $<0.001$ \\
\hline & 7 Feb & $18(85.7)$ & 3 (14.3) & 11.89 & $<0.001$ \\
\hline & 28 Feb & $9(90)$ & $1(1)$ & 7.36 & $<0.01$ \\
\hline \multirow[t]{4}{*}{5} & Pooled & $70(72.2)$ & $27(27.8)$ & 19.74 & $<0.001$ \\
\hline & 10 Feb & 0 & 15 (100) & 20.79 & $<0.001$ \\
\hline & 11 Feb & 36 (90) & 4 (10) & 29.45 & $<0.001$ \\
\hline & $17 \mathrm{Feb}$ & 34 (81) & 8 (19) & 17.32 & $<0.001$ \\
\hline
\end{tabular}

fertilization success in Trios 1, 2, and 3, while the related male was dominant in Trios 4 and 5 (Table 2). Inbreeding occurred in at least 1 batch for each trio.

\section{In vitro fertilization experiment}

The percent occurrence of deformities did not differ between embryos of inbred and non-inbred crosses (Table 3, Fig. 2), or in the average number of deformities per deformed embryo. The 2 most prevalent embryo deformities were unequal cell size and asymmetry; approximately $20 \%$ of the embryos, inbred and unrelated crosses combined, had these 2 deformities (Table 4). Incomplete intercell adhesion was the third most common, with $19 \%$ of all embryos examined showing this deformity, and poorly defined cell margins were seen in $14.9 \%$ of the embryos. The remaining deformities occurred in fewer than $7 \%$ of all the embryos examined. Similar results were found for the percent of larvae with deformities (Fig. 3) and the average number of deformities on each deformed larva (Table 3). The most common larval deformity was a bent tail, affecting $66.9 \%$ of all the sampled larvae. Bent midsections were found on $22.5 \%$ of the inbred larvae and $7.7 \%$ of the larvae from unrelated crosses. Curved spines and malformed yolk sacs were equally prevalent, affecting $8.8 \%$ of the total number of larvae sampled.

Table 4. Gadus morhua. Percent of each type of Atlantic cod embryo and larval deformity found in the inbred and unrelated crosses

\begin{tabular}{|lcc|}
\hline Deformity & Inbred & Unrelated \\
\hline Embryos & & \\
Incomplete intercell adhesion & 18.2 & 19.9 \\
Vacuolar inclusions between cells & 7.7 & 4.3 \\
Cell margins poorly defined & 15.8 & 14.0 \\
Unequal cell size & 20.6 & 20.4 \\
Asymmetry & 20.6 & 22.0 \\
Jumbled & 3.4 & 2.2 \\
Overlapping & 1.0 & 0.0 \\
Extra cell bodies & 2.9 & 2.7 \\
Offset/intermediate & 3.8 & 7.0 \\
Triple & 3.4 & 3.8 \\
Pie & 1.0 & 1.6 \\
Marginal & 1.9 & 2.2 \\
Larvae & & \\
Bent tail & 59.2 & 75.4 \\
Bent midsection & 22.5 & 7.7 \\
Curved spine & 9.9 & 7.7 \\
Malformed yolk sac & 8.5 & 9.2 \\
\hline
\end{tabular}

Table 3. Gadus morhua. Full statistics for deformity, hatch, and starvation data collected for Atlantic cod from the in vitro fertilization experiment: mean $\left( \pm \mathrm{SE}_{i} \mathrm{SD}\right.$ for time to starvation) for inbred and unrelated crosses, the $t$ - or $F$-statistic, and $\mathrm{p}$-value $(\alpha=0.05)$

\begin{tabular}{|lrrrr|}
\hline Variable & Inbred & Unrelated & Statistic & $\mathrm{p}$ \\
\hline Percent occurrence of embryo deformities & & & & \\
Average number of malformations per deformed embryo & $3.06( \pm 0.99)$ & $2.55( \pm 0.90)$ & $t_{(1,8)}=0.95$ & $\mathrm{p}=0.395$ \\
Percent of larvae with deformities & $30.62( \pm 6.91)$ & $34.85( \pm 7.67)$ & $F_{(1,28)}=0.33$ & $\mathrm{p}=0.230$ \\
Average number of deformities on each deformed larva & $0.47( \pm 0.14)$ & $0.39( \pm 0.09)$ & $F_{(1,28)}=2.84$ & $\mathrm{p}=0.104$ \\
Percent hatch & $33.65( \pm 7.20)$ & $42.22( \pm 7.39)$ & $F_{(1,9)}=7.3$ & $\mathrm{p}=0.024$ \\
Time to starvation (d) & $15.42( \pm 1.97)$ & $16.80( \pm 1.95)$ & $F_{(1,553)}=1.31$ & $\mathrm{p}=0.254$ \\
& & &
\end{tabular}




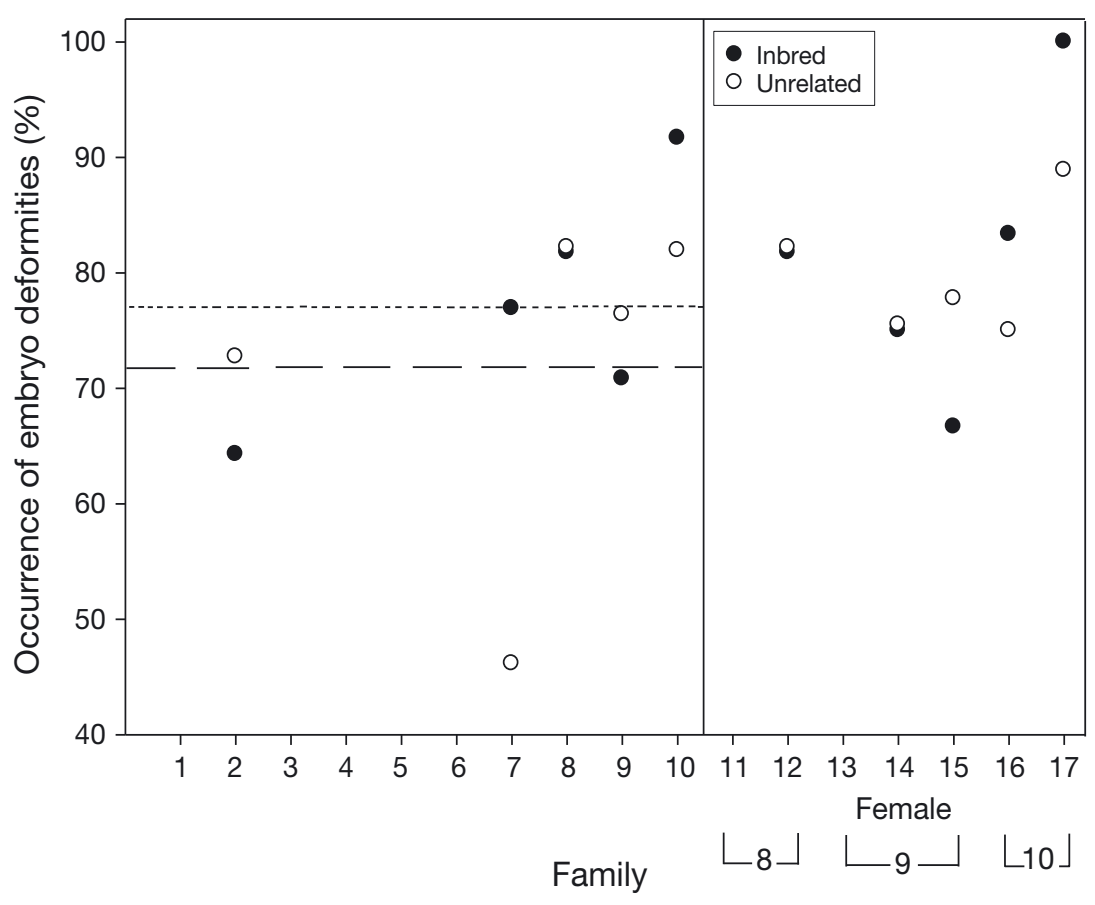

Fig. 2. Gadus morhua. Occurrence of embryo deformities (\%) in the 7 crosses of inbred (filled circles) and unrelated (open circles) Atlantic cod that were photographed at the 4-cell stage. Five of the families (nos. 1, 3-6) and 1 female within Families 8 and 9 could not be photographed at the 4 -cell stage. Short dashed line: mean for inbred offspring; long dashed line: mean for unrelated offspring. Families with $>1$ female are separated in the right panel

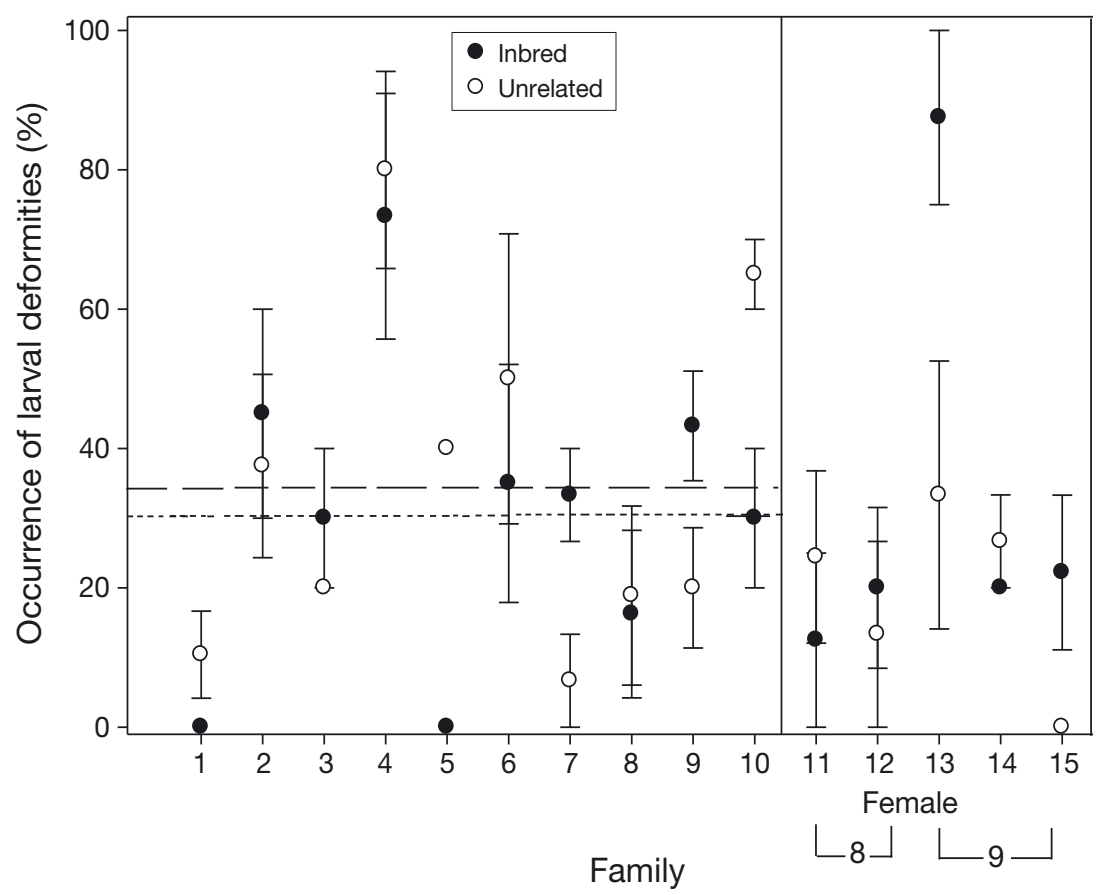

Fig. 3. Gadus morhua. Mean $( \pm \mathrm{SE})$ occurrence of larval deformities (\%) of offspring from inbred (filled circles) and unrelated (open circles) crosses of Atlantic cod at hatch. Short dashed line: mean for inbred offspring; long dashed line: mean for unrelated offspring. Families with $>1$ female are separated in the right panel
The unrelated offspring of both females in Family 9 that were photographed had a higher incidence of embryo deformities (Fig. 2). However, in Family 10, the inbred offspring of each female had more deformities. When it came to larval deformities, there was no consistency between females from Family 8 (Fig. 3). Family 9 was also inconsistent, with 2 females' inbred offspring having more deformities, while the third female's non-inbred offspring had a higher incidence of larval deformities.

Although highly variable, offspring of unrelated crosses had a significantly higher percent hatch than their inbred counterparts (42.2 \pm $7.39 \%$ and $33.6 \pm 7.20 \%$, respectively; mean \pm SE) (Table 3, Fig. 4). In 5 of the inbred crosses and 4 of the non-inbred crosses only 1 embryo hatched from a single beaker (these larvae were only used to measure time to starvation, not larval size). With an $\alpha$ of 0.05 , the only significantly different size measurement was myotome height, where offspring of unrelated crosses had a significantly higher myotome height than their inbred counterparts $\left(F_{(1,28)}=\right.$ $7.72, \mathrm{p}=0.01)$. However, myotome height was not significant after Bonferroni correction $(\alpha=0.01)$. There was no difference in total body length $\left(F_{(1,28)}=2.61, \mathrm{p}=0.118\right)$, eye diameter $\left(F_{(1,28)}=2.13, \mathrm{p}=0.155\right)$, yolk area $\left(F_{(1,28)}=0.12, \mathrm{p}=0.736\right)$, or jaw length $\left(t_{(1,18)}=1.87, \mathrm{p}=0.095\right)$ measurements either (Fig. 5). Time to starvation did not differ significantly between inbred and non-inbred crosses (Table 3, Fig. 6).

\section{DISCUSSION}

The present study is the first to our knowledge that addresses inbreeding in Atlantic cod. Females from the in vivo experiment did not collectively favour one type of male, brother or unrelated, over the spawning period. 


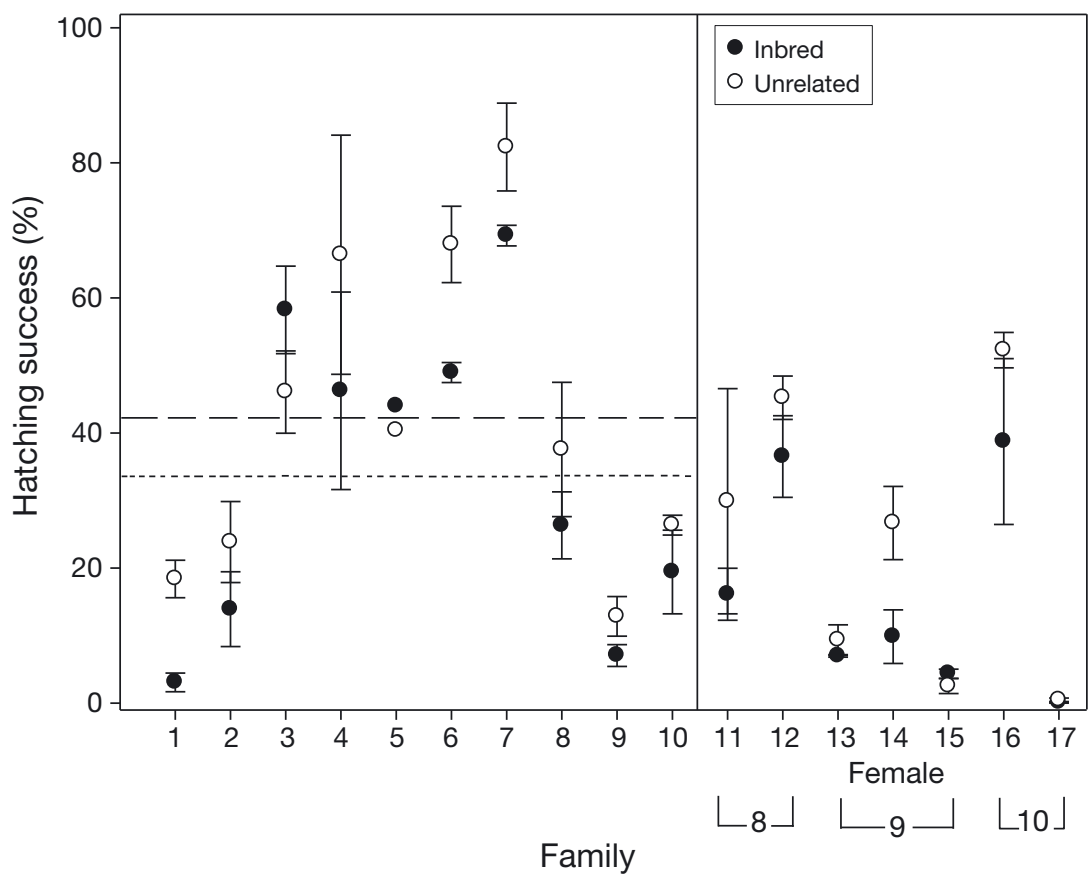

Fig. 4. Gadus morhua. Mean ( \pm SE) hatching success $(\%)$ of offspring from inbred (filled circles) and unrelated (open circles) crosses of Atlantic cod. Further details as in Fig. 2

However, the brother in each of the 5 spawning tanks sired embryos, indicating that inbreeding occurred. Given that cultivated Atlantic cod inbreed and that individuals in sea cages spawn, there may be inbred farmed embryos escaping through the cage netting into the environment. Inbreeding has been shown to have a wide range of negative impacts on rainbow trout Salmo gairdneri, Atlantic salmon Salmo salar, carp Cyrinus carpio, and brook trout Salmo trutta, producing offspring that are less fit for survival than their non-inbred counterparts, even after just 1 generation of full-sibling mating (Cooper 1961, Moav \& Wohlfarth 1963, Ryman 1970, Aulstad \& Kittelsen 1971, Kincaid 1976a,b, Mrakovčič \& Haley 1979, Gjerde et al. 1983). If that is the case with farmed Atlantic cod as well, and our experiment shows that at the very least inbred cod may face reduced hatching success, should any of the escaped embryos hatch and survive to maturity, which has been documented in Norwegian fjords (van der Meeren et al. 2012), they may perform poorly. The percent of embryos that hatched from unrelated parents was significantly higher than those that hatched from related parents, though the difference was modest. The same has been seen in inbred rainbow trout, where inbreeding reduced hatch success by $53 \%$ (Kincaid 1983), and in threespine stickleback Gasterosteus aculeatus, where inbred fish had lower fer- tilization success and decreased hatch success than their non-inbred counterparts (Frommen et al. 2008). On the other hand, the embryos in our experiment did not face any of the potential stressors that the sea cage or wild environment may present (e.g. temperature changes), which could influence hatch success. These results could mean that of the millions of escaped eggs from the sea cages, fewer would be viable long term. In a species where roughly 1 in a million offspring survive to maturity, stocking the cages entirely with full-sibling fish to ensure that only inbreeding occurs could be a means of reducing the chance that even that 1 embryo will live to interbreed with wild cod. Regardless, some escaped embryos or juvenile fish will escape from the cages and survive to reproduce. Therefore, every effort should be taken to investigate other means of eliminating the negative consequences of escapees on wild populations, and aquaculture escapes in general. It is also important to note that while any resulting offspring would be inbred, the fish stocked in the sea cages would not need to be any more inbred than any other net pen with multiple families of fish, just full siblings.

There are several potential limitations to the in vivo experiment. Along with only being 1 generation removed from the wild broodstock, there could have been physical or behavioural differences between males in a tank, rather than relatedness, that influenced female mate choice. Also, in such small tanks, either male could have released sperm and fertilized eggs regardless of female choice. And finally, only half of the females spawned, reducing the sample size. Males in the study were closely matched by colour, length, weight, and condition factor; however, behavioural dominance through aggressive interactions from one male toward the other may have played a role in male fertilization success (Brawn 1961b, Hutchings et al. 1999, Rowe et al. 2008). Future studies may wish to increase the sample size, using fish from different origins and history (particularly a long maintained domesticated broodstock), perform the experiment in sea cages with more potential mates for the females to choose from, and collect embryos from multiple spawning pairs within each tank. In our experiment, while determining that 
Day 1
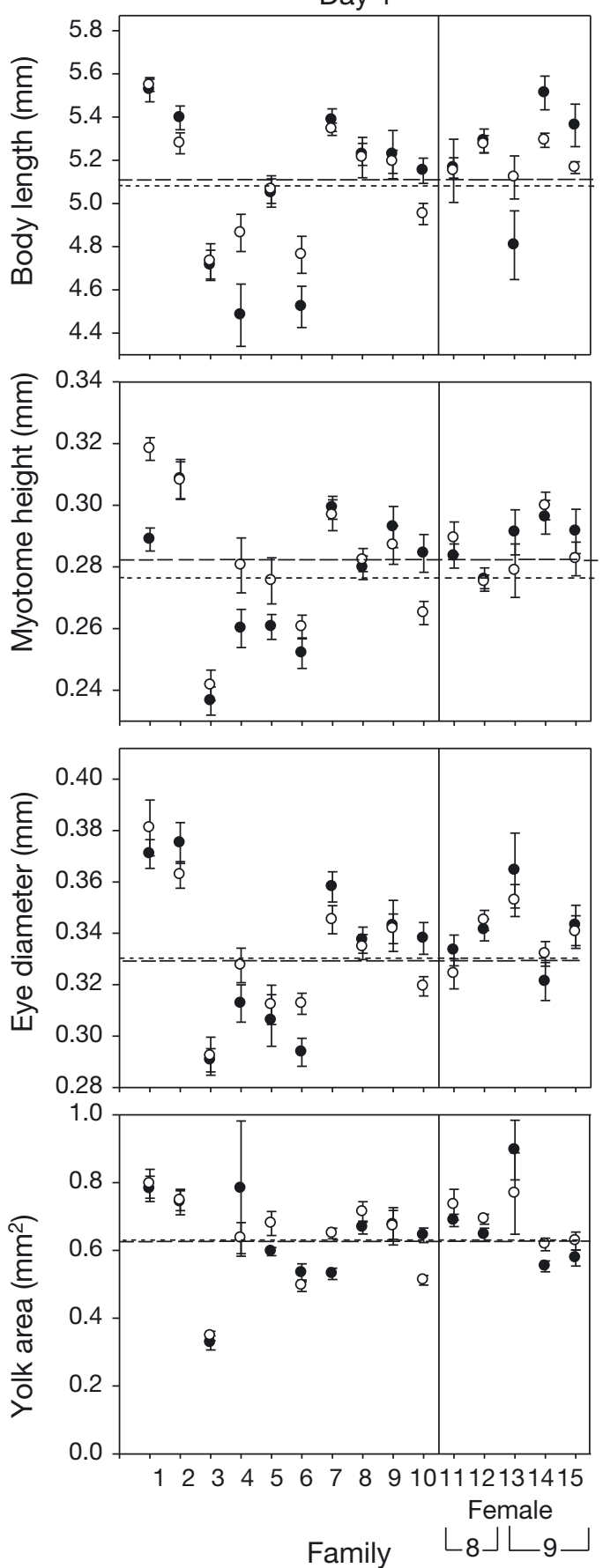

Fig. 5. Gadus morhua. Mean body length, myotome height, eye diameter, yolk area, and jaw length of inbred (filled circles) and unrelated (open circles) Atlantic cod larvae on Days 1 and 5 (jaw length for Day 5 only). Further details as in Fig. 2
Day 5
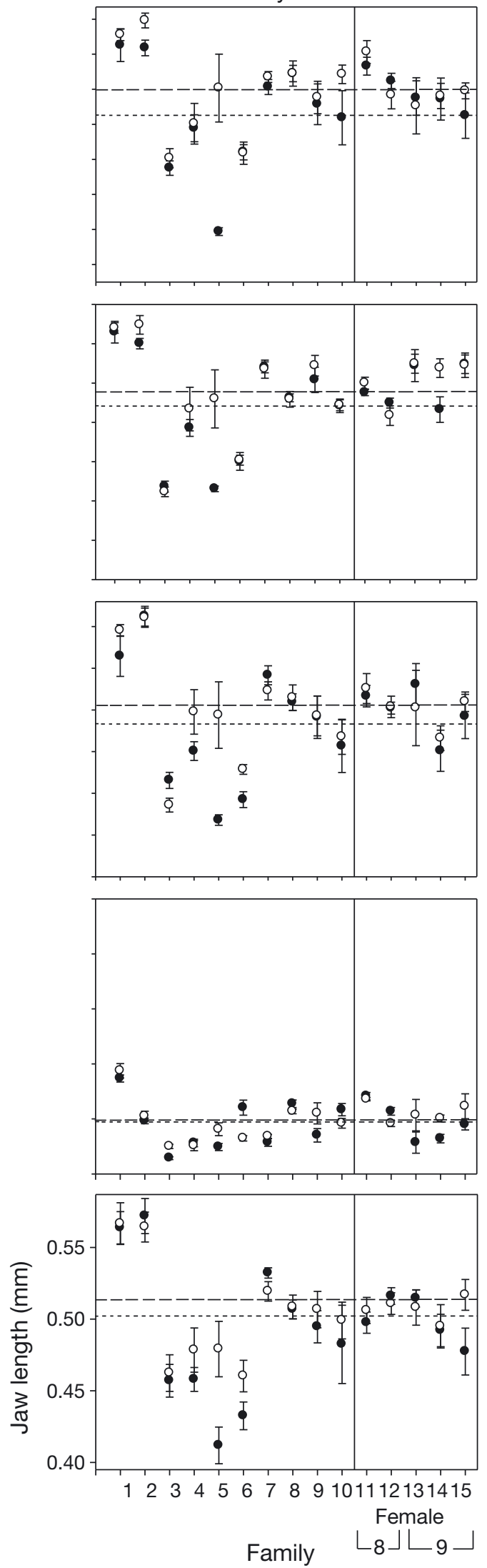


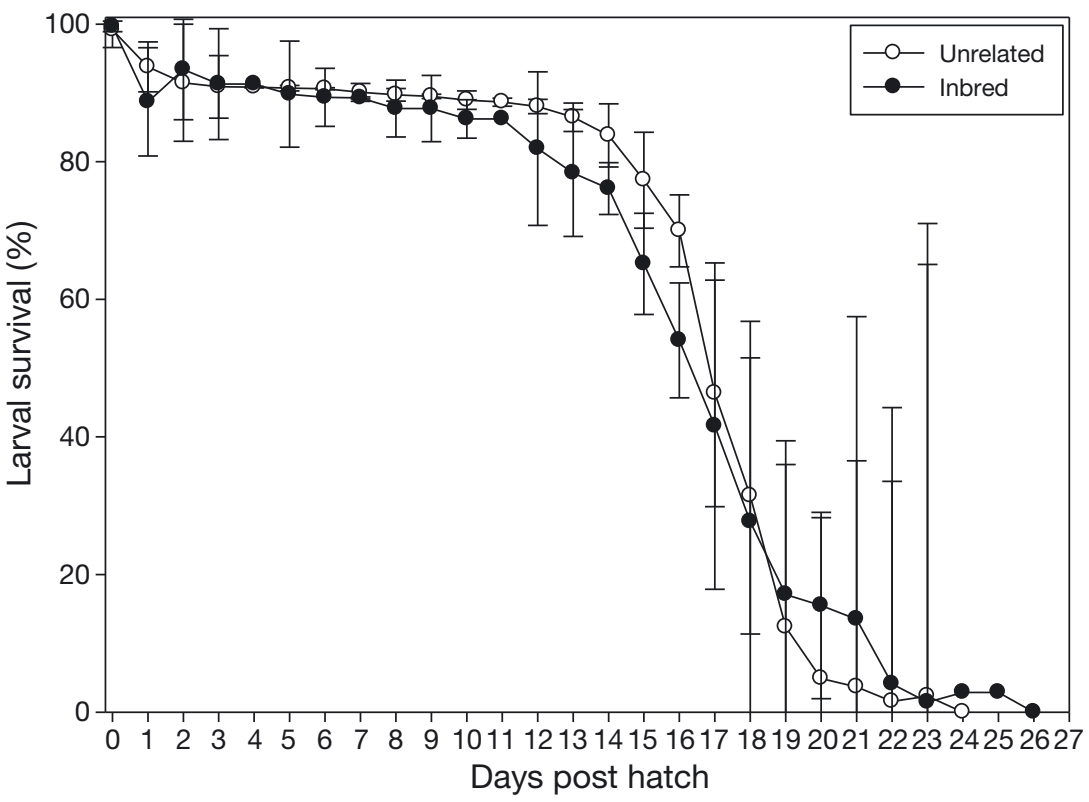

Fig. 6. Gadus morhua. Mean ( $\pm \mathrm{SD}$ ) cumulative larval survival (\%) of offspring from inbred (filled circles) and unrelated (open circles) crosses of Atlantic cod after hatch

inbreeding occurs among cultivated cod, we did not determine whether or not Atlantic cod have kin recognition; future studies may wish to address this.

Some limitations to the in vitro experiment are that deformities were only measured in embryos at the 4cell stage and larvae at hatch, size measurements were limited to hatch and Day 5, and offspring survival was only measured to starvation. There is the possibility that had the resources been available to rear the larvae and examine deformities, size, and survival of individual offspring on a long-term basis, there may have been some observable difference between those of related and unrelated parents. However, most mortality occurs over the period we measured. One study showed that, in relation to maternal effects on larval body size of cod, variation seen in juveniles was still apparent in offspring nearing $2 \mathrm{yr}$ old (Tosh et al. 2010). Another study used otolith backcalculations to determine that fast-growing larvae had better chances of survival in the long term (Campana 1996). Similarly, differing body weights and lengths of sea bass caused by maternal effects were still present at harvest (Dupont-Nivet et al. 2008). If the larvae were reared for a much longer time, subsequent measurements might show that any initial differences could be an indication of long-term size differences. It might also be worthwhile repeating the experiment with a greater number of families and a higher number of females within each family to determine if there would be a noticeable family effect.
If cages could be stocked with only full-sibling fish, all spawning efforts would result in inbred offspring, which may stand a reduced chance of surviving to maturity in the wild, and reduce 1 potential cause of outbreeding depression in wild cod due to aquaculture. There may be concerns about the genetic homogenizing potential on the receiving wild cod population if large numbers of fish from 1 family escaped from a cage, but as it stood in Canadian cod aquaculture, while there were active cod farms, there was already very little family variation in each cage (G. Nardi, GreatBay Aquaculture, pers. comm.). However, it is still important that research continues to determine ways to prevent escapes. Unrelated to inbreeding, 1 particular area in which stocking cages with 1 family of cod could have a very positive effect is in the ability to trace escaped cod back to specific farms, perhaps encouraging more responsible farming practices.

Had we seen a significantly negative effect of inbreeding on first-generation cultivated cod, additional research would be required to determine whether or not the benefit of reducing escaped embryo survival through inbreeding outweighs the potential negative effects of some intentionally inbred farmed offspring mating with wild cod. However, outbreeding as we examine it in this paper relates to the mating of escaped, non-local farmed fish with local populations of wild cod, and the potential for the hybrid offspring to lack some specific local genetic adaptations, therefore being less fit. One generation of full-sibling inbreeding should not create offspring that are significantly more genetically divergent from wild fish than other farmed fish might be, although future studies could perform more indepth research to confirm this. Much of the available research is on salmonids, the life-history traits of which are very different from those of Atlantic cod.

Some work has already been carried out to mitigate the effects of farmed cod spawning with wild cod. The use of $24 \mathrm{~h}$ light exposure in net pens was initiated to halt maturation in cultivated Atlantic salmon and improve farm production (Taranger et al. 1999). It was very effective with Atlantic salmon; thus, photoperiod manipulation was attempted with Atlantic cod. Had it stopped maturation, not only would farmers have seen increased production, as was the origi- 
nal intention, but there would have been no escapes through spawning. Unfortunately, photoperiod manipulation did not have the same effect on farmed Atlantic cod maturation (Porter et al. 1999, Peterson \& Harmon 2005, Taranger et al. 2006, Trippel et al. 2011a). It did, however, delay spawning by several months, which could mean that embryos may face conditions that are less than optimal for survival (different temperature, availability of food, etc.). Other attempts at reducing farmed cod reproductive efforts have included manipulations of their diet (periodic starvation versus full rations) (Karlsen et al. 1995) and triploidy, a process which results in cod with 3 sets of chromosomes, effectively rendering them sterile; this was successful on female cod. Although the males developed testes and sperm, the sperm were aneuploid and therefore sterile (Feindel et al. 2011). At present, as long as cod are able to spawn in sea cages, embryos will escape. Genetic markers have enabled the discovery that eggs and yolk sac larvae can disperse at least $8 \mathrm{~km}$ from net pens due to tidal currents and hydrographical conditions (Jørstad et al. 2008). The strategy of cages stocked with full-sibling fish, combined with triploidy and photoperiod and diet manipulation, could help minimize the occurrence of genetic introgression through release of embryos by spawning cod. More research is needed to determine what, if any, are the long-term effects of inbreeding on first-generation offspring, as well as further tools to reduce the negative effects of aquaculture on wild Atlantic cod populations.

Acknowledgements. This research was funded by Fisheries and Oceans Canada, Memorial University of Newfoundland, and a National Science and Engineering Research Council (NSERC) Strategic grant to Ian A. Fleming, E.A.T., C.F.P, and John Brattey, as well as an NSERC Alexander Graham Bell Canada Graduate Scholarship, a Research and Development Corporation Ocean Industries Student Research Award, and a minor grant from the Silverhill Institute of Environmental Research and Conservation to O.A.P. Fisheries and Oceans Canada provided the monetary and physical resources to carry out the experiments in St. Andrews, NB. We especially thank the Huntsman Marine Science Centre for contributing gametes for the in vitro spawning experiment. The help and support of I. Fleming, E. Yaskowiak, A. Garber, S. Fordham, D. Schneider, N. Feindel, S. Neil, I. Butts, J. Leonard, D. Clarke, M. Kroll, M. Walter, L. Warner, M. Vilimek, T. Hori, and C. Sye is gratefully acknowledged.

\section{LITERATURE CITED}

Ackefors H, Enell M (1994) The release of nutrients and organic matter from aquaculture systems in Nordic countries. J Appl Ichthyol 10:225-241
Árnason T, Björnsson B (2012) Spawning-related mortality in captive Atlantic cod (Gadus morhua L.). Aquacult Res 43:292-296

Auld JR, Relyea RA (2010) Inbreeding depression in adaptive plasticity under predation risk in a freshwater snail. Biol Lett 6:222-224

Aulstad D, Kittelsen A (1971) Abnormal body curvatures of rainbow trout (Salmo gairdneri) inbred fry. J Fish Res Board Can 28:1918-1920

> Aulstad D, Gjedrem T, Skjervold H (1972) Genetic and environmental sources of variation in length and weight of rainbow trout (Salmo gairdneri). J Fish Res Board Can 29:237-241

> Avery TS, Killen SS, Hollinger TR (2009) The relationship of embryonic development, mortality, hatching success, and larval quality to normal or abnormal early embryonic cleavage in Atlantic cod, Gadus morhua. Aquaculture 289:265-273

Bekkevold D, Hansen MM, Loeschke V (2002) Male reproductive competition in spawning aggregations of cod (Gadus morhua L.). Mol Ecol 11:91-102

Bekkevold D, Hansen MM, Nielsen EE (2006) Genetic impact of gadoid culture on wild fish populations: predictions, lessons from salmonids, and possibilities for minimizing adverse effects. ICES J Mar Sci 63:198-208

Brander KM (2007) Global fish production and climate change. Proc Natl Acad Sci USA 104:19709-19714

$>$ Brawn VM (1961a) Reproductive behaviour of the cod (Gadus callarias L.). Behaviour 18:177-197

$>$ Brawn VM (1961b) Aggressive behaviour in the cod (Gadus callarias L.). Behaviour 18:107-147

Butts IAE, Trippel EA, Litvak MK (2009) The effect of sperm to egg ratio and gamete contact time on fertilization success in Atlantic cod Gadus morhua L. Aquaculture 286:89-94

> Campana SE (1996) Year-class strength and growth rate in young Atlantic cod Gadus morhua. Mar Ecol Prog Ser 135:21-26

> Cooper EL (1961) Growth of wild and hatchery strains of brook trout. Trans Am Fish Soc 90:424-438

COSEWIC (Committee on the Status of Endangered Wildlife in Canada) (2010) COSEWIC assessment and update status report on the Atlantic cod Gadus morhua. Available at: www.sararegistry.gc.ca (accessed 25 September 2012)

Dobzhansky T (1950) Genetics of natural populations. XIX. Origin of heterosis through natural selection in populations of Drosophila pseudoobscura. Genetics 35:288-302

> Dupont-Nivet M, Vandeputte M, Vergnet A, Merdy O, Haffray P, Chavanne H, Chatain B (2008) Heritabilities and $\mathrm{G} \times \mathrm{E}$ interactions for growth in the European sea bass (Dicentrarchus labrax L.) using a marker-based pedigree. Aquaculture 275:81-87

Edmands S (1999) Heterosis and outbreeding depression in interpopulation crosses spanning a wide range of divergence. Evolution 53:1757-1768

- Eknath AE, Doyle RW (1990) Effective population size and rate of inbreeding in aquaculture of Indian major carps. Aquaculture 85:293-305

> Feindel NJ, Benfey TJ, Trippel EA (2011) Gonadal development of triploid Atlantic cod Gadus morhua. J Fish Biol 78:1900-1912

> Fitzgerald GJ, Morrissette J (1992) Kin recognition and choice of shoal mates by three spine sticklebacks. Ethol Ecol Evol 4:273-283

Fleming IA, Hindar K, Mjølnerød IB, Jonsson B, Balstad T, Lamberg A (2000) Lifetime success and interactions of 
farm salmon invading a native population. Proc R Soc Lond B Biol Sci 267:1517-1523

Fordham BSE, Trippel EA (1999) Feeding behaviour of cod (Gadus morhua) in relation to spawning. J Appl Ichthyol 15:1-9

Fraser DJ, Cook AM, Eddington JD, Bentzen P, Hutchings JA (2008) Mixed evidence for reduced local adaptation in wild salmon resulting from interbreeding with escaped farmed salmon: complexities in hybrid fitness. Evol Appl 1:501-512

Frommen JG, Luz C, Mazzi D, Bakker TCM (2008) Inbreeding depression affects fertilization success and survival but not breeding coloration in three spine sticklebacks. Behaviour 145:425-441

> Gjerde B, Gunnes K, Gjedrem T (1983) Effect of inbreeding on survival and growth in rainbow trout. Aquaculture 34: 327-332

- Hansen LA, Dale T, Damsgård B, Uglem I, Aas K, Bjørn PA (2008) Escape-related behaviour of Atlantic cod, Gadus morhua L., in a simulated farm situation. Aquacult Res 40:26-34

> Hart PR, Purser GJ (1995) Effects of salinity and temperature on eggs and yolk sac larvae of the greenback flounder (Rhombosolea tapirina Günther, 1862). Aquaculture 136: 221-230

- Heggberget TG, Johnsen BO, Hindar K, Jonsson B, Hansen LP, Hvidsten NA, Jensen AJ (1993) Interactions between wild and cultured Atlantic salmon: a review of the Norwegian experience. Fish Res 18:123-146

> Hindar K, Ryman N, Utter F (1991) Genetic effects of cultured fish on natural fish populations. Can J Fish Aquat Sci 48:945-957

- Hutchings JA (1991) The threat of extinction to native populations experiencing spawning intrusions by cultured Atlantic salmon. Aquaculture 98:119-132

> Hutchings JA, Fraser DJ (2008) The nature of fisheries- and farming-induced evolution. Mol Ecol 17:294-313

Hutchings JA, Bishop TC, McGregor-Shaw CR (1999) Spawning behaviour of Atlantic cod, Gadus morhua: evidence of mate competition and mate choice in a broadcast spawner. Can J Fish Aquat Sci 56:97-104

$>$ Jensen Ø, Dempster T, Thorstad EB, Uglem I, Fredheim A (2010) Escapes of fishes from Norwegian sea-cage aquaculture: causes, consequence and prevention. Aquacult Environ Interact 1:71-83

> Jørstad KE, van der Meeren T, Paulsen OI, Thomsen T, Thorsen A, Svåsand T (2008) Escapes of eggs from farmed cod spawning in net pens: recruitment to wild stocks. Rev Fish Sci 16:285-295

> Karlsen Ø, Holm JC, Kjesbu OS (1995) Effects of periodic starvation on reproductive investment in first-time spawning Atlantic cod (Gadus morhua L.). Aquaculture 133:159-170

Kelly LA, Stellwagen J, Bergheim A (1996) Waste loadings from a freshwater Atlantic salmon farm in Scotland. J Am Water Resour Assoc 32:1017-1025

Kennedy CJ, McDonald LE, Loveridge R, Strosher MM (2000) The effect of bioaccumulated selenium on mortalities and deformities in the eggs, larvae, and fry of a wild population of cutthroat trout (Oncorhynchus clarki lewisi). Arch Environ Contam Toxicol 39:46-52

Kincaid HL (1976a) Effects of inbreeding on rainbow trout populations. Trans Am Fish Soc 105:273-280

Kincaid HL (1976b) Inbreeding in rainbow trout (Salmo gairdneri). J Fish Res Board Can 33:2420-2426
Kincaid HL (1983) Inbreeding in fish populations used for aquaculture. Aquaculture 33:215-227

Kjesbu OS, Solemdal P, Bratland P, Fonn M (1996) Variation in annual egg production in individual captive Atlantic cod (Gadus morhua). Can J Fish Aquat Sci 53:610-620

McDonald JH (2009) Handbook of biological statistics, 2nd edn. Sparky House Publishing, Baltimore, MD

McGinnity P, Stone C, Taggart JB, Cooke D and others (1997) Genetic impact of escaped farmed Atlantic salmon (Salmo salar L.) on native populations: use of DNA profiling to assess freshwater performance of wild, farmed, and hybrid progeny in a natural river environment. ICES J Mar Sci 54:998-1008

- McGinnity P, Prodöhl P, Ferguson A, Hynes R and others (2003) Fitness reduction and potential extinction of wild populations of Atlantic salmon, Salmo salar, as a result of interactions with escaped farm salmon. Proc R Soc Lond B Biol Sci 270:2443-2450

Moav R, Wohlfarth GW (1963) Breeding schemes for the genetic improvement of edible fish. Prog Rep 1962, Fish Breeders Association of Israel

> Moe H, Gaarder RH, Olsen A, Hopperstad OS (2009) Resistance of aquaculture net cage materials to biting by Atlantic cod (Gadus morhua). Aquacult Eng 40:126-134

Mrakovčič M, Haley LE (1979) Inbreeding depression in the zebra fish Brachydanio rerio (Hamilton Buchanan). J Fish Biol 15:323-327

> Naylor RL, Goldburg RJ, Primavera JH, Kautsky N and others (2000) Effect of aquaculture on world fish supplies. Nature 405:1017-1024

Naylor R, Hindar K, Fleming IA, Goldburg R and others (2005) Fugitive salmon: assessing the risks of escaped fish from net-pen aquaculture. Bioscience 55:427-437

Nordeide JT, Folstad I (2000) Is cod lekking or a promiscuous group spawner? Fish Fish 1:90-93

Peterson RH, Harmon PR (2005) Changes in condition factor and gonadosomatic index in maturing and non-maturing Atlantic salmon (Salmo salar L.) in Bay of Fundy sea cages, and the effectiveness of photoperiod manipulation in reducing early maturation. Aquacult Res 36:882-889

> Porter MJR, Duncan NJ, Mitchell D, Bromagea NR (1999) The use of cage lighting to reduce plasma melatonin in Atlantic salmon (Salmo salar) and its effects on the inhibition of grisling. Aquaculture 176:237-244

> Rakitin A, Ferguson MM, Trippel EA (2001) Male reproductive success and body size in Atlantic cod Gadus morhua L. Mar Biol 138:1077-1085

> Read P, Fernandes T (2003) Management of environmental impacts of marine aquaculture in Europe. Aquaculture 226:139-163

> Rideout RM, Trippel EA, Litvak MK (2004) Paternal effects on haddock early life history traits. J Fish Biol 64:695-701

> Rowe S, Hutchings JA, Skjaeraasen JE, Bezanson L (2008) Morphological and behavioural correlates of reproductive success in Atlantic cod Gadus morhua. Mar Ecol Prog Ser 354:257-265

Rudolfsen G, Figenschou L, Folstad I, Nordeide JT, Soreng E (2005) Potential fitness benefits from mate selection in the Atlantic cod (Gadus morhua). J Evol Biol 18:172-179

Ryman N (1970) A genetic analysis of recapture frequency of released young of salmon (Salmo salar L.). Hereditas 65:159-160

Saillant E, Chatain B, Fostier A, Przybyla C, Fauvel C (2001) Parental influence on early development in the European sea bass. J Fish Biol 58:1585-1600 
Shields RJ, Brown NP, Bromage NR (1997) Blastomere morphology as a predictive measure of fish egg viability. Aquaculture 155:1-12

Skaala O, Wennevik V, Glover K (2006) Evidence of temporal genetic change in wild Atlantic salmon, Salmo salar L., populations affected by farm escapes. ICES J Mar Sci 63:1224-1233

Sokal RR, Rohlf FJ (1995) Biometry: the principles and practice of statistics in biological research, 3 edn. W.H. Freeman \& Co., New York, NY

Su G, Liljedahl L, Gall GAE (1996) Effects of inbreeding on growth and reproductive traits in rainbow trout (Oncorhynchus mykiss). Aquaculture 142:139-148

Svåsand T, Kristiansen TS, Pedersen T, Salvanes AGV, Engelsen R, Nævdal G, Nødtvedt M (2000) The enhancement of cod stocks. Fish Fish 1:173-205

Taranger GL, Haux C, Hansen T, Stefansson SO, Björnassen BT, Walther BT, Kryvi H (1999) Mechanisms underlying photoperiodic effects on age at sexual maturity in Atlantic salmon, Salmo salar. Aquaculture 177:47-60

Taranger GL, Aardal L, Hansen T, Kjesbu OS (2006) Continuous light delays sexual maturation and increases growth of Atlantic cod (Gadus morhua L.) in sea cages. ICES J Mar Sci 63:365-375

Thorsen A, Trippel EA, Lambert Y (2003) Experimental methods to monitor the production and quality of eggs of captive marine fish. J Northwest Atl Fish Sci 33:55-70

Thorstad EB, Fleming IA, McGinnity P, Soto D, Wennevik V, Whoriskey $F$ (2008) Incidence and impacts of escaped farmed Atlantic salmon Salmo salar in nature. NINA Spec Rep 36. Norwegian Institute for Nature Research, Trondheim. Available at www.nina.no/archive/nina/ PppBasePdf/temahefte/036.pdf (accessed 12 September 2012)

Tosh JJ, Garber AF, Trippel EA, Robinson JAB (2010) Genetic, maternal, and environmental variance components for body weight and length of Atlantic cod at two points in life. J Anim Sci 88:3513-3521

Trippel EA, Neil SRE (2004) Maternal and seasonal differences in egg sizes and spawning activity of northwest Atlantic haddock (Melanogrammus aeglefinus) in rela-

Editorial responsibility: Tim Dempster, Trondheim, Norway tion to body size and condition. Can J Fish Aquat Sci 61: 2097-2110

Trippel EA, Kraus G, Köster FW (2005) Maternal and paternal influences on early life history traits and processes of Baltic cod Gadus morhua. Mar Ecol Prog Ser 303: 259-267

> Trippel EA, Rideout RM, O'Reilly PT, Herbinger CM, Neil SR, Hamilton L (2009) Communal spawning leads to high potential for inbreeding in gadoid aquaculture. Aquaculture 296:27-35

Trippel EA, Neil SR, Puckrin OA, Dickinson L, Powell F (2011a) Effects of extended photoperiods and light intensities on growth, sexual maturation and tissue water content of Atlantic cod (Gadus morhua) in sea cages. Can Tech Rep Fish Aquat Sci 2925

Trippel EA, Rise ML, Gamperl AK, Johnson SC and others (2011b) Development of genomics tools and elite broodstock for Atlantic cod culture in Canada. World Aquacult 42:50-54

van der Meeren T, Jørstad KE, Paulsen OI, Dahle G (2012) Offspring from farmed cod (Gadus morhua L.) spawning in net pens: documentation of larval survival, recruitment to spawning stock, and successful reproduction. ICES CM 2012/P:11

> Viken A, Fleming IA, Rosenqvist G (2006) Premating avoidance of inbreeding absent in female guppies (Poecilia reticulata). Ethology 112:716-723

> Ward AJW, Hart PJB (2003) The effects of kin and familiarity on interactions between fish. Fish Fish 4:348-358

> Weir LK, Hutchings JA, Fleming IA, Einum S (2005) Spawning behaviour and success of mature male Atlantic salmon (Salmo salar) parr of farmed and wild origin. Can J Fish Aquat Sci 62:1153-1160

Wesmajervi MS, Westgaard JI, Delghandi M (2006) Evaluation of a novel pentaplex microsatellite marker system for paternity studies in Atlantic cod (Gadus morhua L.). Aquacult Res 37:1195-1201

Zimmermann EW, Purchase CF, Fleming IA (2012) Reducing the incidence of net cage biting and the expression of escape-related behaviours in Atlantic cod (Gadus morhua) with feeding and cage enrichment. Appl Anim Behav Sci 141:71-78

Submitted: November 19, 2012; Accepted: June 21, 2013 Proofs received from author(s): September 28, 2013 